Three faces of context and their implications for career: A study of public sector careers cut short Laurie Cohen and Joanne Duberley

laurie.cohen@nottingham .ac.uk (corresponding author)

Paper submitted to journal of Vocational behaviour, October 2015 


\title{
Three faces of context and their implications for career: a study of public sector careers cut short
}

\begin{abstract}
This paper examines the impact of context on careers. It is based on a study of senior managers in an English Local Authority. It offers two important contributions: first, an empirical contribution examining how context matters to individuals in their career-making in the setting of the UK public sector. Our findings point to three aspects or faces of context: proximal events, ideology and enduring structural features. The first, context as ideology, attends to meaning-making that is collective in nature, and that incorporates concepts of power, domination, subordination and resistance. Our second refers to the enduring structural features. These are on-going trends and developments, predictable and traceable over the medium to long-term which offer rules and resources, thus structuring opportunity and constraint. Finally, the third face, context as proximal events, refers to (often unexpected) contingencies that arise at particular moments. Although bounded both spatially and temporally, they can significantly impact on career decision making. The second contribution of the paper builds upon this empirical base to develop theoretical and conceptual understanding of the link between career and context, illustrating the interconnectedness of the various faces of context and the dynamic ways in which these influence careermaking over time.
\end{abstract}

Key words: Context, Ideology, Career, Public Sector,

\section{Introduction}

Between 2008 and 2011 the face of English local government was transformed. In the wake of the global financial crash and the austerity agenda that followed, local authorities faced large cuts to budgets and huge swathes of public sector workers were made redundant. Such a fundamental reshaping raises many questions about the people who had spent their working lives within public sector organizations suddenly facing very different futures to the ones they had envisaged. We are privileged to have been given unique access to a group of senior employees who had worked together for over two decades in the social services department of an English local authority (which we are calling Starling County Council - SCC), 
and who left between 2010 and 2011, mainly taking advantage of early retirement packages that were available for a short time at the height of the budget cuts. What makes this group unusual and compelling from a research perspective is (a) the longevity of their working relationships; (b) that they are of a similar age (they were all born between the mid-1940s and mid-1950s); and (c) that years after leaving SCC they continued to regularly meet up as a group. They are therefore well-placed to provide insights into careermaking in a local authority social services department and the impact of the financial crisis on employees' working lives.

Theoretically, we are interested in the nature and role of context and contextual change in the process of career-making. Richardson (2000) suggests that 'rapid change, while stressful and anxiety-provoking, also provides unique opportunities to see more clearly the impact of the social system on the individuals in that system' (p. 197). We agree. Given the scope of the financial crisis and austerity agenda, their profound implications for public sector work and workers, and the pace of change, we see SCC as an ideal site in which to examine the interplay of career and context. In this dynamic and highly politicized setting context is not some shady and obscure place in the background, but instead played a very immediate and visible role both in people's everyday experiences of work and over time. It was a permeating feature of all of our discussions with respondents, generating heated and passionate debate. By tracing respondents' career stories, from the decision to join the public sector social services through to the decision to leave, we examine the broad question of how we can conceptualize the role of diverse contextual features in the development of career.

Our analysis attends to both individual and collective accounts. This is important because one of the limitations of the careers literature is a dominant view of the career as an individualized phenomenon. Over the years careers scholars have critiqued this 'under-socialized' approach (Mayrhofer, Meyer \& Steyer, 2007), instead configuring career-making as a social process (Cohen, Duberley \& Mallon, 2004). Indeed, within vocational psychology there is a notable seam of research that highlights this collective dimension (Richardson, 2000; Blustein, Schultheiss \& Flum, 2004; Schultheiss, 2007; Savickas, Nota, Rossier, Dauwalder, Duarte, Guichard, Soresi, Van Esbroeck and Van Vianen 2009; Blustein, 2011). 
However, within the field this remains a minority perspective. In this paper we draw upon individuals' recollections and shared histories in order to develop a richer picture of their complex, multi-faceted work setting, and examine how its evolution intersected with their own career-making.

In what follows we begin by considering how context has been conceptualized in the careers literature. Next we briefly introduce 'Career-making at SCC and Beyond' and present our research design. From there we present our findings. We offer two important contributions: Our first contribution lies in the identification of three faces of context and the various ways in which these matter to individuals in their career- making in the setting of the UK public sector. The second contribution of the paper builds upon this empirical base to develop theoretical and conceptual understanding of the link between career and context, illustrating the interconnectedness of the various faces of context and the dynamic ways in which these influence career-making over time.

\section{Conceptualising Context}

In the book Outliers social commentator Malcolm Gladwell argues that context matters: 'The culture we belong to and the legacies passed on by our forebears shape the patterns of our achievement in ways we cannot begin to imagine... This is not a book about tall trees. It is a book about forests' (2008, p. 19-20). These are his concluding words:

My great-great-great grandmother was bought at Alligator Pond. That act, in turn, gave her son, John Ford, the privilege of a skin color that spared him a life of slavery. The culture of possibility that Daisy Ford embraced and put to use so brilliantly on behalf of her daughters was passed on to her by the peculiarities of the West Indian social structure. And my mother's education was the product of the riots of 1937 and the industriousness of Mr Chance. These were history's gifts to my family - and if the resources of that grocer, the fruits of those riots, the possibilities of that culture, and the privileges of that skin tone had been extended to others, how many more would now live a life of fulfilment, in a beautiful house high on a hill (p. 285). 
Somewhat less dramatically, this is the stuff that careers research is made of. It is increasingly being recognized that context influences career, not just in terms of the employing organization but also wider social, economic, cultural and political settings (Duffy \& Dik, 2009; Patton \& McMahon, 2015). Indeed it has been suggested that the increasingly turbulent occupational environment means that wider social context is now more salient than ever (Ali, Fall \& Hoffman, 2013; Grote and Hall, 2013).

Writing about organizational behavior generally rather than careers specifically, Johns (2006) suggests that 'contextual features are often studied in a piecemeal fashion, in isolation from each other' (2006, p. 389) and, we would add, depicted as quite distinct from the people who inhabit them. In contrast, in this paper we are interested in the mutuality of individuals and the diverse settings in which they are situated. Thus we construe context not as a benign backdrop, but as part of the action. However, an enduring criticism of the field relates to the decontextualization of career theory (Hanchey \& Berkelaar 2015; Patton, Doherty \& Shield, 2014; Kang \& Gottfrredson, 2015). This is often traced back to the origins of much career theorizing in the discipline of psychology where, McMahon et al (2014, p. 37) argue, wider environmental-societal influences may be seen as distal or indirect. An alternative explanation relates to the focus of much careers research on a fairly homogenous group - largely Western, white collar workers (Richardson, 2000; Dries, 2011), with only limited interest in issues of class, ethnicity/race and gender, and insufficient attention to those with little volition (Duffy \& Dik, 2009; Ali et al, 2013; Blustein, 2011).

Nevertheless, a growing group of scholars agrees with Gladwell on the centrality of context to careermaking (Savickas et al, 2009; Schultheiss, 2007; Gunz \& Mayrhofer, 2011; Blustein, 2011; Inkson, Gunz, Ganesh and Roper, 2012; McMahon et al, 2014), conceptualizing context in a variety of ways and vividly describing the diverse features through which people make their moves. (Kaulisch \& Enders, 2005; Lee, Kossek, Hall \& Litrico, 2011; Al-Ariss, Koal, Özbilgin,\& Suutari, 2012; Hanchey \& Berkelaar, 2015). In recent years vocational psychologists such as Blustein, Schultheiss and Flum have introduced a relational perspective on work and career (Blustein et al, 2004; Schultheiss, 2007; Blustein, 2011). Critiquing what they see as the overly voluntaristic and individualized understandings that predominated in the literature, they propose a theory based on the idea of career development as a collective process, rooted in complex 
and profound relationships and commitments, and attending to issues of inequality. For Schultheiss (2007), career cannot be extracted from its context. Rather, her relational cultural paradigm depicts career (in her words 'worklife'), relationships and culture as inextricably fused. We can only understand these dimensions in relation to one another. Similarly, the idea of work and career development as deeply social activities underpins Blustein's relational theory of working. As he explains, 'we tend to work with others, which places working into an explicit social context; moreover, people throughout the life span and across the life space give working life meaning and context' (2011, p. 14). We see these relational perspectives as offering significant possibilities for what we research and how research it, and they certainly resonate with the study at hand. Not only were our respondents' lives profoundly entangled with one another, but in addition their social arrangements and connections beyond the group - at home, work and in their wider communities, were central to their career-making. However, in this analysis we want to move beyond relationships and interpersonal interactions to consider meso level entities such as employing departments and the services they provide, organizations, professions, and political structures, to more fully understand how these features inform and influence people's career-making.

Mayrhofer et al (2007) outline three grand social theories which offer insights into the link between structure and action in careers: the social theory of Pierre Bourdieu, the structuration theory of Anthony Giddens and the theory of autopoietically closed systems of Niklas Luhmann. Conceptually, our starting point is a structuration (Giddens, 1984) framework originally put forward by Stephen Barley (1989) and adapted by Duberley, Cohen and Mallon (2006). Informed by Wright et al.’s (2000) linkage of the work of Weick (1995) and Giddens (1984) which shows how meaning making is informed by both events and the wider horizon of the lifeworld, their respondents' career worlds are depicted as diverse and contradictory, including a range of institutions (e.g. organizational, family, scientific, governmental, national/cultural) whose imperatives are not consistent or uniform. At times of rapid change, as was the case in SCC, the salience of such features and their contradictions becomes starker and more apparent (Richardson, 2000).

This point mirrors other studies within the careers literature that present context as multi-layered and multi-dimensional (Mayrhofer et al, 2007; Al-Ariss et al, 2012) or as permeating themes or strands (Eaton 
\& Bailyn, 2000; Kaulisch \& Enders, 2005; Lee et al, 2011; Mainiero \& Sullivan, 2005). Within vocational psychology, McMahon and her colleagues $(2014 ; 2015)$ have developed a Systems Theory Framework which maps the inter-related, recursive systems in which individuals are situated, through which they make their career moves and over time establish career trajectories. Duffy and Dik (2009) take a different tack, moving beyond the identification of contextual features to examine how certain factors, salient at the time of a particular career decision, serve to enable, constrain and shape people's choices. Duffy and Dik maintain that because much of the research in vocational psychology is based on people with high levels of volition (and hence for whom context seems less constraining), how context matters is still a largely open question. Whilst we agree with their sentiment, we would argue that context matters to everyone regardless of their status; though, of course, we support Duffy and Dik's contention that persistent inequalities result in very different levels of access to important career resources, which leads to widely divergent experiences of enablement and constraint. Also, we agree that there is still much to learn about the relationships between people, contexts and careers.

Thus our aim is to examine what context does and unpick the various ways in which individuals make sense of their context and its influence upon the process of career-making. Our approach is inductive. During the course of this research respondents described the many ways in which their landscapes had changed during their tenure at SCC. In telling their stories they positioned themselves within these settings, recounting how they engaged with them and with what implications, highlighting the on-going interaction between structure and agency. In our analysis we will present what our respondents saw as the key changes in their career landscapes and how, in career terms, they mattered.

\section{Methodological approach and research design}

As discussed above, this research program initially had two aims. The first was an empirical one, to better understand the career implications of the financial crisis and the austerity agenda for people working in the services whose budgets were cut. The second was more theoretical, to study the nature and role of context and contextual change in the process of career-making. In this paper we focus on the latter. The study is based on in-depth accounts of eleven senior managers who developed their careers within the 
social services department of an English local authority and who left in late 2010/early 2011 as a consequence of deep public sector budget cuts (see table 1 for details of the participants). As noted above, this group is significant not only because the people in it worked together for so many years and left at roughly the same time in similar circumstances, but also because they continued to meet up as a group long after leaving.

\section{Table1}

The sample

\begin{tabular}{|llll|}
\hline Name & $\begin{array}{l}\text { Age on leaving } \\
\text { NCC /Sex }\end{array}$ & $\begin{array}{l}\text { Years working } \\
\text { with NCC }\end{array}$ & Job prior to leaving \\
\hline Paul & $57 / \mathrm{M}$ & 22 years & Service Head and Associate Director \\
Jim & $60 / \mathrm{M}$ & 25 years & Service Head \\
Michael & $58 / \mathrm{M}$ & 25 years & Service Director \\
Roger & $64 / \mathrm{M}$ & 26 years & Service Head \\
Laura & $55 / \mathrm{F}$ & 27 years & Service Head \\
Tanya & $56 / \mathrm{F}$ & 27 years & Service Head \\
Jane & $57 / \mathrm{F}$ & 28 years & Service Head \\
Josie & $59 / \mathrm{F}$ & 33 years & Locality Manager \\
Jonathon & $66 / \mathrm{M}$ & 23 years & Programme Manager \\
Penny & $59 / \mathrm{F}$ & 28 years & Service Manager \\
Caroline & $57 / \mathrm{F}$ & 39 years & Commissioning, Strategy, Performance \\
& & & Manager \\
\hline
\end{tabular}

The starting point of our research is that the organizational world is socially constructed and that individuals are 'knowledgeable agents' in that they can 'know what they are trying to do and can explain their thoughts, intentions and actions' (Gioia, Corley \& Hamilton 2012, p. 17). The qualitative data were generated in three broad stages. The first was through in-depth individual interviews (Kvale, 1996), lasting between an hour and an hour-and-a-half. The second stage was a group interview in order to enable our participants to explore their collective views (Patton, 2005), follow up key issues and test out our interpretations. This included eight of the original eleven respondents. This was followed by a third stage in which we met with the three outstanding respondents. With permission of respondents from the first group, we used their transcript as a starting point for this discussion. In addition to these formal stages, throughout the period of data generation, several respondents participated in email exchanges and discussions about their experiences and their developing thoughts of the project. We had not anticipated this level of involvement, but it added an iterative, reflexive dimension that we were pleased to 
incorporate. Finally a copy of this paper was sent to all respondents and they were invited to comment on it. This sparked further discussion with three of the respondents. One issue that we had to consider was that two members of the group were known to the first author (this is how we knew of the group's existence) and that this relationship might have an impact upon their willingness to open up during interviews. For this reason, the second author conducted initial interviews with these people.

Critics might point to our small, homogeneous sample as a limitation of the study. We recognize this point, and would not claim generalizability of our specific findings. Our respondents are a relatively privileged group. They were all senior managers when they left SCC, they all have professional social work qualifications and all but one is educated to degree level. They therefore had access to very different opportunities than respondents in some other studies of unemployment (Ali et al, 2013). None had planned to resign from their SCC when they did, and all had expected the latter years of their working lives to unfold differently. Although it is beyond the scope of this paper to explore their transition in detail, it is important to recognize that that as a group they found the transition traumatic. However, in contrast to other studies of unexpected unemployment (see for example Ali et al, 2013; Forrett, Sullivan \& Mainiero, 2010), having accrued significant social and cultural capital over the years, they were in a position to make choices. Although they are not representative of all workers, we would argue that the intensity and duration of this group's collective experience coupled with the combination of individual and group-level data, generated in both formal and informal, spontaneous settings offer a depth and richness which is unique, providing insights which are valuable both in their own right and in establishing an agenda for future research.

At the outset of the interview respondents were asked to tell their career story. They spoke of their reasons for embarking on careers in the public sector and background experiences (including family, education and training) that led to those decisions, and of how their careers evolved at SCC. Compared to many other studies we have done, what resounded so clearly in these data was (a) the intensely political nature of public service, circumscribed by a dense web of national and local policies, agendas and interests, and (b) how these imperatives are deeply entangled in wider social attitudes and ideologies. Together these 
factors had a profound influence on respondents' day-to-day work and longer-term career possibilities. Respondents also described SCC's handling of the austerity conditions following the financial crisis, of their own decisions to leave and how this was managed.

Interviews were fully transcribed and analyzed using a 'bottom up' approach (Shepherd \& Sutcliffe, 2011) in which descriptive, open coding techniques were used to fully examine the data, and then moving on to axial coding to develop second order themes (Van Manaan, 1979; Silverman, 2000). These themes were used to construct the guide for the group interview - the second stage of data generation. As noted above, our purpose here was to test out our interpretations and gain further insight into our respondents' collective memory. Key issues we explored included changing perceptions of public service and citizenship; generational factors (e.g. why it matters, in career and organizational terms, that this group of people grew up in the 1960 s and trained in the 70 s and 80 s); redundancy/retirement as an individual vs a collective experience and gender differences in post SCC decisions and experiences.

We incorporated the group data into our analysis using the same two-step process: open, descriptive coding followed by more conceptual, second order analysis. Following Gioia et al (2012), the first order analysis uses informant-centric codes and a second order analysis developed from this using concepts and themes which are more researcher-centric reflecting issues arising from our analysis of the literature (Van Maanen, 1979). Thus, using Hammersley and Atkinson's (1995) notion of 'progressive focusing', we moved from first order descriptive codes to second order conceptual ones. This means that we were able to give voice to our respondents in the early stages of data collection, analysis and reporting, but that our second order analysis moved beyond this to develop researcher generated codes. We also examined all data which were not associated with a particular theme, and looked out for contrasting and minority views to ensure that our analysis is based on all of the respondents' voices. We re-read the contents of each theme and discussed the contents between ourselves to develop our understanding of the individual themes and relationships between them. As discussed earlier, in line with Bansal and Corley's (2011) recommendations concerning transparency, we showed transcripts to interviewees and discussed our evolving analysis with them. They were also given the opportunity to comment on this paper. This 
'participant' checking can be argued to offer a validity check on evolving interpretations. Indeed Guba and Lincoln (1989, p. 239) argue that it offers 'the single most crucial technique for establishing credibility'.

The final stage of the analytic process was the agglomeration of second order codes into three central themes. We cannot argue that this was a purely inductive process as it is clear that our sense making and the frame we bring to understanding the data will have been influenced by our understandings of existing concepts from the literature (Weick, 1995). This process enabled the generation of what (following Johns, 2006) we have termed three overlapping faces of context. We use the term face for two reasons. First we feel that each face brings into the foreground a different aspect of the whole, in the same way that looking at one face of a building or an object emphasizes particular features whilst obscuring others. However, each face is only part of the whole and these different aspects or manifestations of context are interlinked, together impacting on individual career-making over time (Johns, 2006, p. 387). In the next section we will outline these faces and examine their roles in the career-making of our respondents. It is important to note that our aim here is not to list out every element of context that individuals identified. Rather, we have highlighted the dimensions that were most salient in respondents' accounts and were seen to have particular implications for their career-making. In other words we are interested in the way that context matters - how people account for the impact of context on their careers.

\section{Findings}

\subsection{Context as ideology}

Three key faces of context emerged in our data analysis. Table 2 below illustrates the development of the first of these - context as ideology 
Table 2

Context as ideology

\begin{tabular}{|l|l|}
\hline First Order (Descriptive)Themes & Second Order (Analytical) Themes \\
\hline Societal ideologies & \\
Professional ideologies & \\
Service ideologies & Epoque \\
Development of profession & Society \\
Meaning of work & Profession \\
Self in role & Service \\
Family backgound & \\
Education & \\
\hline
\end{tabular}

As shown in table 2 above, a key theme to emerge from our data collection related to the role of ideology as a shaper of meaning. This is an important finding because with some notable exceptions (Richardson, 2000), within the careers literature there is a lacunae when it comes to issues of ideology. And yet, as we will go on to illustrate, ideology and ideological positioning underpinned much of our respondents' career thinking and enactment. Indeed, as Meyer (1982) argues, ideologies (construed as 'constellations of shared beliefs that bind values to actions') 'shape their adherents' worlds. They legitimize certain actions, render other actions heretical, and create meanings for events that have yet to occur' (p. 530). In the case of SCC, the prevailing ideology at the time when our respondents were embarking on their careers in social work and social care was strikingly different from the world that they left in late 2010/early 2011, with contradictory perspectives on the purpose of public service, how it should operate and what a career in public service might look like.

Our initial data analysis led to the development of three broad dimensions of ideology: social values, attitudes and perceptions; the profession and the service. We have added the concept of époque because when recounting their long careers at SCC, respondents used decades as a central organizing logic, echoing Rossi's (1992) emphasis on the importance of 'period effects'. They associated meanings with decades ('the 60s were like this, but the 70s were like that') and explained how these meanings evolved 
and/or endured over time. With respect to careers, this was significant because these meanings circumscribed what was possible, important and legitimate at any one time. An important issue here was the power of prevailing beliefs and values when respondents were in their formative years - during school and university and as young adults being socialized into their new occupational communities (Mannheim, 1936/1998). Often the beliefs and values that came to define a particular decade cascaded down through the social work and social career sector, and to the SCC department of social services, but not always. Sometimes ideological 'cracks' emerged between these spheres through which respondents had to navigate. Cracks also began to surface when patterns of meaning making evolved in ways that clashed with respondents' personal ideologies. In the following sections we develop these points, using extracts from the data as illustrative examples.

Discussing their reasons for embarking on careers in the public sector, most of the respondents talked about being 'children of the $60 \mathrm{~s}$ ', and their commitment to particular ideological perspectives that were prevalent among young people at the time that they were exploring possible career paths:

It was a combination of things like it was for an awful lot of people in the late 60s/early 70s, which was a combination of, I would say, left wing idealism, really a sense in which we wanted to build a fairer, less stigmatizing society with greater equality for all and a sense that if we went into this area of work, social work in particular, that there was something about it being empowering, enabling people to improve their lives and to enable them to do that in a supportive way... I suppose there was a whole direction of young people saying, 'I don't just want to work for profit, I don't just want to go into a company, I don't want to work for Marks \& Spencer as a buyer. I actually want to make a difference'. (Josie)

Respondents explained how these principles served to frame their developing ideas about the nature and purpose of work. From this perspective, work and career provided an opportunity to live out their ideals. To these young people in the 1960s and 70s, social work appeared to be uniquely suited to this aspiration: 
People who got into social services in the 1970s... there was much more of a political dimension to the work. (Paul)

It was our lives. It was more than just a job.... (Penny)

The public sector, and social services departments in particular, were likewise seen as forces for change'. I think probably again most of the people that you will interview would have thought there were opportunities to make real changes in society, and actually combat deprivation and poverty. (Paul)

Our data thus suggest a link between the ideological tenor of the broader society (or at least that section of society in which respondents positioned themselves), their chosen profession and the nature of the organization in which that profession operated. There has been a great deal of research into the importance of the 'exploration' phase for the development of people's career self-concepts and their career world views (Super, 1990; Savickas, 2005). This importance was certainly apparent in the accounts we heard, as reflected in comments like the one below made in the first group interview: 'I suppose I grew up there. I suppose we all did. [some agreement]. Yeah, we grew up there.'

However, because this research tends to be based on psychological perspectives and frameworks, it rarely attends to collective dimensions, to issues of ideology beyond the level of the individual or to generational effects (Mannheim, 1936/1998). This leads to a general neglect of wider questions of legitimacy - what is seen as appropriate and even 'normal' at a particular moment in time. Our SCC respondents spoke at length about the ideological settings in which their early ideas were sown and how they served to frame their career thinking and action. Importantly, their views and positions were not presented as singular, idiosyncratic musings, but as indicative of their peer group, family and their putative occupational community. Indeed, in both individual and group interviews we noticed that in discussing 'why and 'how' questions, respondents frequently used the pronoun 'we' rather than 'I'. This usage served to highlight the importance of these shared understandings for respondents' ideas about what they hoped to be and do in 
career terms. Being part of a collective was a defining and enduring source of ratification and legitimation, powerfully prescribing what, in career terms, was seen as morally acceptable, valued and what was morally suspect. Notably, the salience of respondents' early experiences did not fade as their careers developed. Rather, these experiences underpinned their evolving career self-concepts, and were used as ideological reference points in their developing narratives.

The relationship between time period, societal, professional and service ideologies was a feature of all of the accounts we generated. Another vivid example was the advent of new public management (also referred to as managerialism) that took hold in the 1980's and 90s, with profound implications for all three spheres:

[Society] The Thatcher administration clearly did a whole load to try and dismiss the public sector... The media and the public world had become much more critical of what it was that social services was doing... We were becoming collectively, corporately certainly more defensive as a result of it (Michael).

[Service] The new managerialism of course that was embedding itself in the late 1980s and the 90s was impacting on the county council and at the same time the huge impact of performance culture emanating from central government under New Labour was beginning to impact on the way the county council and the social services department saw itself... The times I heard we must learn from the business sector (Jim).

[Profession] A kind of character or kind of persona in [social work] management and senior management that was slightly different to that which had gone on in the previous 10 years. Performance oriented and get the story right at all costs become a more dominant situation (Jim).

In the focus groups, respondents talked about their early ideological commitments and reflected on how, over their long careers at SCC, a gulf had opened up between their personal values and those of the profession, service and wider society. Here Michael reflects on this growing schism: 
We've identified ourselves as a group and held together as a group who belonged to a certain era and a certain way of thinking. And now the world's changing we're a bit on the side because, you know, we were good guys and girls and now the world's a bad place (Michael).

In career terms this changing landscape had profound implications, not only for the status of social work and what it was seen to be for, but also for the way social work was organized, how it was practiced, for the roles and opportunities if offered, and for the kind of people who were valued and able to progress through the ranks. Significantly, although they disagreed profoundly with many of the changes to their profession and service (particularly in the later years), during their time at SCC all of the respondents achieved hierarchical advancement. They were candid in recognizing the ideological tensions that sometimes resulted from this progression and explained how they attempted to manoeuvre within these changing imperatives in order to stay true to their beliefs. This was especially difficult during the radical restructuring that was introduced in the wake of the financial crisis.

Respondents described this tension at various points in their accounts, but in 2010 it became unbearable. The schism between what the service was becoming and their own professional (political and personal) meaning systems was at a tipping point. For the majority of respondents, taking early retirement was the only way to retain a sense of professional integrity.

\subsubsection{Responding to changing meaning systems}

Our final point on context as ideology relates to others' perceptions of social workers. We have portrayed respondents as 'children of their times' and highlighted examples of synchrony between the professional, service and wider societal meaning systems in which they were embedded. However, we have also identified tensions. Most respondents talked about social workers being increasingly under attack. This resulted in a kind of vigorous defensiveness that permeated the accounts we heard. As Paul described: 
I think in a way there's a sense in which you sometimes end up being a bit of a Millwall supporter [a UK football club whose fans have a reputation for aggressive loyalty that sometimes boils over into violence] - you know, "They all hate us and we don't care!" ... But obviously you were always in that environment of feeling that you couldn't do right for wrong or wrong for right, that whatever you did was wrong.

Two important points emerge from this quote. The first is that in our data ideology worked in two ways: normatively to define the purpose and process of social work and social care at SCC, and conversely to judge, criticize and dismiss not only social workers themselves and the SCC social services department, but the whole social work profession (and even in some cases the whole public sector). This critical seam featured strongly in our data, picking up pace and salience with each passing decade. Respondents vividly described the shift from the optimism of the 1970s, when the Seebohm report heralded a whole new approach to social work and social care, to an increasingly sour and critical public perception which viewed social workers, at best, as well-meaning but somewhat irrelevant participants in an ineffective and overpaid public sector, or at worst as incompetent meddlers who turned a blind eye to abuse. The second, related point is that this public onslaught led to on-going identity work (Watson, 2008) as a ubiquitous characteristic of both individual and group accounts. This is not to suggest that respondents depicted themselves as inward-looking victims of popular opinion. Rather, as Millwall supporters they were energetic, often angry and certainly up for the fight. Frequently in the public eye and faced with these contested prescriptions, their careers were never presented as smooth or predictable, but rather as constantly in flux: defended and transformed in relation to (overlapping, sometimes clashing) prevailing meaning systems.

\subsection{Context as enduring structural features}

Interlinked with the idea of context as ideology, running through our respondents accounts of their careers was a more structural face, the enduring structural features which defined the rules and resources available to individuals. In the quote at the start of the literature review Malcolm Gladwell highlights the importance not only of ideological patterns but also their related systems - economic, educational and 
political dimensions that together configured the structures of opportunity available within which he and his family were situated. Likewise our respondents described the intertwined systems within and outside SCC that determined, to some extent, the available opportunities and constraints. As Table 3 represents, these included political and domestic systems and arrangements, as well as professional and service ones. Of course ideology underpins this analysis, and it is important to note that enduring structural features are situated ideologically, reflecting and at the same time constituting particular ideological positions. However, like a cubist painting that examines the different 'faces' of an object but does not claim that these faces work in isolation, we recognize that the faces we are examining are always part of a whole. Although it is useful to separate them out analytically in order to better understand how they work, they make little sense on their own. In this part of our analysis we are mainly focusing on the political environment and domestic arrangements. This is for three reasons. First, because the previous section focused strongly on service and profession and paid relatively little heed to the political sphere; second, because we often speak of the relevance of government arenas but frequently fail to articulate just how they matter to people's career-making; and third, because domestic arrangements are likewise extremely important, but are sometimes pushed to the sidelines in favor of the workplace here and now. 
Table 3

Context as enduring structural features

\begin{tabular}{|c|c|}
\hline First order (Descriptive) themes & Second order (Analytical) themes \\
\hline $\begin{array}{l}\text { Development of professions } \\
\text { Development of service }\end{array}$ & $\begin{array}{l}\text { Political environment } \\
\text { - Orientation to public sector } \\
\text { - Resources } \\
\text { - } \quad \text { Professional practices } \\
\text { - }\end{array}$ \\
\hline $\begin{array}{l}\text { SCC HR strategies, policies and practices } \\
\text { Structures of career opportunity }\end{array}$ & $\begin{array}{l}\text { The Profession } \\
\text { - Structures and structural change } \\
\text { - Public perceptions } \\
\text { - values }\end{array}$ \\
\hline $\begin{array}{l}\text { Local government, policies impacts } \\
\text { National government change, policies, impacts }\end{array}$ & $\begin{array}{l}\text { The Service } \\
\text { - } \quad \text { structures and structural change } \\
\text { - values: training and development } \\
\text { - values: innovation } \\
\text { - tenure }\end{array}$ \\
\hline Domestic roles and responsibilities & $\begin{array}{l}\text { Domestic roles and responsibilities } \\
\text { - } \text { structures } \\
\text { - work/family orientation } \\
\text { - geographical location }\end{array}$ \\
\hline
\end{tabular}

\subsubsection{Political environment}

As noted in the Introduction, it was the imposition of the austerity agenda by the UK central government, in the wake of the financial crisis, that triggered our research and we therefore expected the central government to loom large in respondents' accounts. It did, but even more significant was the local administration, and our respondents spoke about this at length. In particular, the orientation of the local council towards the public sector was paramount: its purpose, and its relationship with the private sector and civil society. For years the local council had been led by the Labour party, and respondents were used to working with elected members who believed in the value of a strong public sector. As Tanya explains:

Labour were in power [locally] obviously and very sort of Old Labour, so believed in public services. They saw us as their eyes and ears. They wanted us to be the best we could be so they could hold us to a standard and expect others to meet our standards, minimum, and they felt that 
that was a very strong position to be in. They liked us having decent buildings, well trained staff, that sort of thing.

However, taking over in 2009 , the Conservative party saw things very differently. In the following quote Jonathan vividly describes this change in orientation:

Locally when the county council went Conservative after 20-odd years of being Labour it was like a vegetarian inheriting a butcher's shop really. I mean they just didn't know what to do with it. They couldn't dismantle it completely, but they really didn't understand why people couldn't pull themselves up by their own boot straps and people couldn't look after themselves. "Why are we spending all this money on supporting people?" if you like. So that was a difficult time.

Of course the parties' orientation to the public sector was partly a matter of ideology, partly a matter of economics, realpolitik and whatever it would take to get re-elected. But our concern here is how and why this mattered in career terms. Specifically, respondents talked about how it impacted on both resources and their professional practice. Permeating our dataset was a view that struggles over resources are a central feature of public sector work. In Michael's words, ‘Nothing just happens in public services. Behind the scenes there is always a fight for resources'. How this struggle played out was closely related to the local council's priorities and commitments. Because the Labour council believed in the importance of the public sector and saw it as a vehicle for innovation and change, they saw adequate resourcing as a priority. This is not to suggest that funds were ever unlimited, but that there was a commitment to the work of the public sector and its employees. As Michael explained, 'I was lucky it was a Labour administration, sort of Blair years, growth in money, hard, hard stuff. We did develop a lot of things and since I've left a lot of it's been dismantled'. In career terms, the Labour council's support of Social Services meant that on a day-to-day level there were resource to invest in staff, as Tanya highlighted in the quote above about quality and training. Respondents also spoke of opportunities for learning and growth, and more widely for career advancement. Linked to this was an emphasis on innovation, which encouraged respondents to seek out challenges and take risks. Because the council prided itself on being at the cutting edge of social 
service thinking and practice, some respondents were able to develop their reputations on the national stage and contribute to initiatives far beyond SCC. As Jim explains:

It was one of the first truly multidisciplinary teams in Britain at the time. Amazing. Fantastic experience. So that was really buzzy ... I said earlier that I was interested in this link of theory and practice. Because we were so leading edge I got loads of articles published in Community Care Magazine and other magazines, social work magazines, because I could see the practice we were doing at that point - closing asylums, creating alternatives, doing community developmentit was so exciting and so leading edge that I just had to write about it.

Critics might point to a certain nostalgic gloss to these data and we would answer them in two ways. First, while these quotes might suggest a rosy view of an idealized past, this was not ubiquitous; indeed, our individual and group transcripts are replete with challenge and scepticism. Second, it is not our purpose here to pass judgement on the successive political administrations, but rather to highlight the ways in which local government was seen to matter in career terms. Our respondents described how during the Labour administration there was a confluence of belief in the value of the public sector, (some) resource provision, and a commitment to innovative practice that together created an environment in which they saw themselves as contributing to a growing service (indeed their own careers developed hand-in-hand with the service that they were helping to build), had the freedom to try new approaches and to develop their practice, and with opportunities with respect to hierarchical advancement. As Jonathan described in the 'vegetarians taking over a butcher shop' quote, the Conservative council which succeeded Labour in 2009 did not understand the role of the public sector in the same way and saw innovation as largely the prerogative of private enterprise. With budget cuts, restructuring and many functions outsourced to the private sector, this had severe consequences for career possibilities within Social Services and for how social care and social work were practiced on a daily basis.

It is important not to assume that what has been thus far described as a mainly enabling situation under Labour and a mainly constraining one under the Conservatives should be seen as determining people's 
career fates. First, notwithstanding the salience of government agendas, these did not operate in isolation but rather were deeply entangled with other imperatives at work in respondents' professional and personal lives. Second, the ways in which people engaged with these structures of opportunity were not uniform. Indeed, even amongst respondents who, in some important ways, were quite a homogenous group, there was considerable variation. This is vividly depicted in the two quotes below. The first, from Jim's interview, presents a highly agentic picture. Although the new administration appeared to be constraining, Jim managed to create some quite remarkable career opportunities. This is in stark contrast to Josie's feelings of having very little room for manoeuvre, highlighted in the second quote.

I mean that was a narrowing of my role, but actually because what I had focused my previous decade in was actually trying to work out how best to integrate health systems and local government systems, particularly in mental health services ten years previously, I viewed this as an absolutely fantastic opportunity to try and bang some heads together because I knew how to do it... That was very strong for me. (Jim)

I think I hated the way it was and what had changed. I just didn't want to be a part of dismantling services that I'd spent a lifetime building up. It was like soul destroying to start seeing them all disappear being sold off to the private sector. They were all things that I just couldn't politically or idealistically actually agree with and struggled to actually feel that I was doing anything meaningful when I had to co-operate (Josie)

Although the local administration had a stronger presence than the central government within the dataset, this is not to suggest that the influence of the central government was not relevant. On the contrary, these spheres were described as interacting in interesting ways. At times the local council was presented as translating and implementing central initiatives at the local level, as Penny suggested: 'There wasn't money coming down from central government to local government and members were making decisions about how to allocate the resources they did have'. However, there were also instances where there appeared to be a more direct route between respondents, in their Social Services roles, and central 
government agendas. Here Jonathan's story about David Cameron's ‘big society’ initiative was especially interesting. Jonathan was interested in preventative work with older people, and he explained how he skilfully navigated between agencies to achieve the best results. Although in many ways his work was becoming ever more constrained by cuts in resources and the dismantling of the Social Services infrastructure, the Conservative government's emphasis on the 'big society' offered a legitimate space for him to manoeuvre, effectively bypassing the local council's jurisdiction: 'It helped us when David Cameron came in and started saying those words about the community and voluntary sector because obviously we were saying "Well, we're doing it. You know, this is it",

From this data we get a picture of embedded and overlapping contexts, national, regional and local/departmental. It is also important to remember the other contexts that influence career including individuals' domestic responsibilities. It is to this area we now turn.

\subsubsection{Domestic arrangements and responsibilities}

Domestic arrangements emerged as important environmental features in some of our data, mainly during the individual rather than the group interviews, and more often in the woman's accounts than in the men's. This is no surprise because whereas the group discussions focused mainly on participants' shared experiences of work, in the one-to-one sessions, participants had more freedom to tell their individual stories. As for the gender split, given generational considerations, this finding was not unexpected. Although we do not have the scope to examine the interplay of these faces of context with gender, it is indeed an important consideration that merits investigation in its own right.

In the data, respondents spoke of domestic matters in terms of three key dimensions: geographical arrangements, domestic structures and arrangements and career centrality. Geographical arrangements concern respondents' decisions to either stay in or move to the case study city. For some this was a professional matter - because they had been offered a position in the local authority, but others moved for family reasons. For example, Paul and his wife thought it would be a nice place to raise their young family, while Laura felt unable to move away because of her husband's mental health problems. These 
long-term, personal decisions had significant career consequences, both in terms of available opportunities, but also for commitment, identity and for the sense of affiliation that was such a striking feature of our data. As noted earlier, our respondents agreed that they had 'grown up' at SCC.

Family structures concerned who did what at home and we were interested in why this mattered in career terms. It came as no surprise that more women than men raised these issues. However, the ways in which they raised them did not conform to stereotypes. Both Laura and Caroline described their central, caring roles: however, for Laura this was a consequence of her husband's health difficulties, and for Caroline, who waited a long time for a child, it was a conscious and very deliberate decision. In spite of her responsibilities, Laura continued to dedicate much of her time and energy to her career. Caroline, in contrast, chose to prioritize her daughter, and compromise on career advancement:

I would be ferrying the girls to wherever they needed to be in the evening, working long hours and there didn't seem to be anything pretty much left after that so it did feel quite consuming (Laura).

I didn't have [my daughter] till I was 40 and I'd waited a long time for her, so I wasn't going to miss her once I'd got her... So I didn't actively seek progression really because if I'd gone for that it would have had different requirements and I didn't feel I wanted to do that (Caroline).

Although before her daughter was born Caroline had been primarily work-oriented, this changed when she became a mother. For other mothers, though, work orientation remained central throughout. This meant that on a day-to-day basis they worked very long hours, saw themselves as central in terms of shaping their services, and were well placed to take advantage of opportunities for career advancement as they arose. Tanya and Josie both described themselves in these terms. However, in making these decisions they were well aware that they were transgressing deeply-rooted expectations and values about women, work and motherhood. This is vividly described in this short exchange with Tanya: 
(Interviewer) You described yourself as a workaholic... how central was the job to your life during those 27 years?

Totally total, to my shame I suppose in many ways.

(Interviewer) Why shame?

Well, it was put before family... I suppose the hardest time was when I was a single parent for a couple of years. That was the hardest time because I still put the job first. ... I'm lucky my kids always understood that. They always saw why... But as I said, I couldn't have done what I did for them without working.

This is a good example of the interplay of ideology and structural dimensions. Although Tanya's home and work arrangements were compatible enough to allow her scope to develop her career, unfettered by conflicting responsibilities in terms of day-to-day management, this did not shield her from prevailing ideological imperatives. She was free to and did 'go against the grain' of dominant expectations, and yet this was not without consequences for her sense of self, leading to some harsh judgements about the kind of woman and mother she was.

\subsection{Context as proximal events}

Thus far many of the dimensions that we have considered stretched out over the long term. This final empirical section, however, focuses on contextual jolts - unexpected events that significantly impacted on respondents' day-to-day lives at SCC and their subsequent career decision-making. Table 4 outlines those identified by our respondents. Although the terminology connotes a sense that this face might be more 'bounded' than the others, this is not to suggest that ideological and enduring structural features are not relevant in the case of proximal events. Rather, these jolts are experienced as interruptions in these longestablished patterns, which is precisely what makes them so important (Duffy \& Dik, 2009). Our data supports Meyers' suggestion that 'members imbue jolts with ideological interpretations' (1982, p. 516). Indeed, with respect to the first jolt we are considering, the financial crisis, it was the stark recognition that the emergent ideology was so far away from what they had always seen as the meaning and purpose of their work. It is to this event that we will turn now. This will be followed by a consideration by of more 
personal events that impact career decision making: the birth of a child, the loss of a spouse, family health issues and domestic crises.

\section{Table 4}

Context as proximal events

\begin{tabular}{|c|c|}
\hline First order (Descriptive) themes & Second order (Analytical) dimensions \\
\hline Financial crisis & Financial crisis \\
\hline Austerity agenda & - nature of work \\
\hline Service ideology & - purpose of work \\
\hline Professional ideology & - feelings about role \\
\hline Meaning of work & - resources \\
\hline Career aspirations & - position and status \\
\hline Self in role & Personal contingencies \\
\hline National Government change/policies etc & - purpose of work \\
\hline Decision to leave & - feelings about role \\
\hline Family roles and responsibilities & \\
\hline
\end{tabular}

\subsubsection{The financial crisis}

The consequences of the financial crisis, triggered by the 2008 banking crash, permeated both individual interviews and group discussions. For all but one of our respondents, it was what triggered their departure from SCC, through a voluntary severance package offered to cut staff costs. In this paper we do not have the scope to examine how the crisis impacted on respondents' post-retirement lives. Instead, we will focus on their final years at SCC, touching on the nature of the work and purpose of their work, their feelings about work, resources and career opportunities: thus bringing together ideological and structural elements discussed separately in the previous two sections.

There was a consensus that the financial crisis and the subsequent austerity program imposed on UK local authorities fundamentally changed the nature of social work and social care. Far from the ideals of building a more equal society, focusing on prevention, standing beside less advantaged members and enabling disenfranchised people to have a voice, the new reality was defined by dismantling services and meeting ever more stringent targets. This quote from a participant in the second focus group is a good 
example: '[The] latter years of my work were spent deconstructing. I mean my whole life was redundancies and savings and restructuring, and getting rid, really'. All of our respondents saw the austerity measures as heralding a new way of thinking about the purpose of their work. Of course this is not to suggest that before this all had remained as it was when they joined the service back in the 1970s. Indeed, our data on ideology revealed a steady evolution in thinking and practice over the decades. But what happened after 2008 was not simply part of this incremental development; rather, it was seen as a radical transformation. A participant in the second focus group explained:

Your whole career was around trying to make something that you thought was a good service in your own way, but the last year or two were just the opposite of that really... we had a particularly unpleasant set of councilors who were very, very ideologically driven to kind of deconstruct the state. It wasn't just about them having to make cuts that they didn't really want to make, which is the current situation at County Hall. It was these people were delighting in making those cuts.

As the data so far presented vividly convey, the jolt was both ideological and material, with departments closing and deep cuts to resources which were seen as vital to keep the service going. Laura described how this process impacted on staff training and development:

There was a significant element of the budget there which was for supporting external providers to provide services for the people of Starling and those budgets were being cut significantly and all at the time that we were in the senior leadership team there would be stories of concerns constantly, which I think isn't odd. You would expect that this would be the case, but concerns always about service delivery and people's vulnerability and, you know, what's going on behind closed doors in those establishments that our vulnerable people are going into. And instead of being in a position to do something with that we were saying "Well okay, we won't train them". 
For these senior managers, the program of austerity that followed the financial crisis fundamentally changed the nature of their jobs. Instead of building the service they were now helping to dismantle it, while at the same time trying to keep things running:

The last year or so I'd kind of worked ridiculous hours in the job because I was doing the Supporting People job, but I was also acting up as assistant director as well. So I was trying to do both jobs half time, but actually I was really doing both jobs full-time, if you like. So I was doing about 60 or 70 hours a week. It was just a crazy time in my life, but also it was all devoted to making savings, cutting services, and I was trying to come up with ways of reducing the budget in my Supporting People thing without shifting too much distress onto the users of the service (Paul).

Obviously this pressure had significant consequences for individuals, physically and emotionally as well as for their sense of who they were. Discussing his final decision to leave Jim, who we have quoted earlier as seeing opportunities everywhere, explained, 'If I'd stayed I was going to be cramped like a concertina, pushing in to such an extent that I would have to become a cynical, glass half empty person'.

\subsubsection{Personal contingencies}

In addition to major economic and social events, proximal events also include the more personal, individual or family events that provide the context for an individual's career decision making. All of our respondents gave examples of issues that arose in their life outside work that impacted upon their careers in different ways, for example Tanya discussed the birth of her second son:

I personally had a bit of a tragedy in the late '80s. I had my first son in '83 and then I had my second son in '86 and he was born with Down Syndrome, but my husband decided that he would stay at home and become the stay at home parent. In a way it added a personal perspective to what I was already doing really and confronted any sort of residual prejudices I may have had as well which was quite an interesting one to go for. I then had my daughter in '89 and after that I wanted to change. I'd been a team manager in that area for about 8 years while I had my family 
in effect and I applied for and secured a senior professional officer job which was based at County Hall with county-wide responsibility for learning disabilities that had then become more of a focus for me in a professional as well as a personal way.

Others talked about how when close friends or family became ill or when grandchildren were born it made them take stock and evaluate their career choices going forward. For some this made them increasingly aware of a rift that had opened up between them and their organisation, as the values that underpinned the Council's current operations diverged dramatically from their own. In several cases this triggered the eventual decision to leave.

\section{Discussion and conclusion}

This study adds to the growing body of literature highlighting the importance of context for the study of careers (Blustein, 2011; Gunz \& Mayrhofer, 2011; Gunz, Mayrhofer \& Tolbert, 2011; Savickas et al, 2009; Schultheiss, 2007; McMahon et al, 2014 ). The first contribution of the paper relates to the way in which context operates by shaping opportunities and constraints in a variety of different ways. As stated earlier, our aim in this study was to gain an understanding of how context matters to careers. Whilst undertaking our analysis we were drawn to the ideas of Gary Johns (2006). Johns' takes a more micro approach then we have taken here, focusing on the context for organizational behaviour and looking in particular at how aspects of context can influence particular individual level variables such satisfaction. His work is aimed at challenging the fundamental attribution error - the tendency to overemphasize dispositional causes of behaviour at the expense of situational causes (Johns, 2006, p. 403). We believe that an over emphasis on the individual level of analysis can also be seen in the careers field where historically more attention has been given to psychological factors in career decision making than social ones. Whilst our approach is significantly different to Johns', utilizing a qualitative methodology, we have shown in this paper how context as enduring structural features, as proximal events and as ideology play an important role in career decision making. This builds upon previous studies by considering the different faces of context and the ways in which aspects of context are interwoven, challenging the ideas of context as a model of neat, concentric circles with each layer influencing the one below/within it. 
As discussed in the findings, context as ideology matters to issues of identity, affiliation, legitimacy. In other words it influences what is seen as possible/impossible; legitimate/illegitimate; desirable/undesirable and is reflected in people's discussions of the meaning and purpose of their working lives. Context as enduring structural features highlights the existing institutions and structures of opportunity which define and prescribe what is available, possible and impossible (although of course there are also ideological and affiliation elements to this as we show in the analysis). Finally proximal events provide unexpected challenges that impact upon both structures of opportunity and ideas about the meaning and purpose of work, and identity. Importantly, though, these 'faces' of context are not mutually exclusive - there is a lot of slippage between these career preoccupations/dimensions, and also between the faces themselves, of course. For example, ideology both underpins the others, but is also a consequence of the others.

This study also highlights an additional important aspect of context relating to time and space. These were significant features in respondents' accounts: specifically the importance of what Mannheim (1936/1998) called 'generational effects'. In our data, there was a strong feeling that being born and raised in a particular place at a particular moment in history mattered deeply and had implications not only for respondents' initial career choices, but also for how they engaged with SCC and sought to develop their careers over the long term. In his seminal essay he argued that:

Early impressions tend to coalesce into a natural view of the world. All later experiences then tend to receive their meaning from this original set, whether they appear as that set's verification and fulfillment or as its negation and antithesis. Experiences are not accumulated in the course of a lifetime through a process of summation or agglomeration, but are 'dialectically' articulated in the way described (1936/1998, p. 177).

The desire to use one's career to build a better society permeated our dataset and all respondents talked with enthusiasm of how they had worked to achieve this. There was also a great deal of discussion about 
how later changes in their work environment including increased bureaucratization had placed them in positions where they felt that their goals were no longer attainable and that despite very high workloads, service was declining. Participating in the dismantling of a service that they had spent nearly three decades building underpinned most of our respondents' decisions to leave SCC. Our data thus elucidate the importance of history in understanding careers. In particular the study has shown how changes in ideology over time play out in career terms. This is an important point as it is an area that is often neglected in careers research where a psychological perspective has tended to dominate and there has been less concern with issues of power, domination, subordination and resistance.

The second contribution of this study relates to a fundamental difficulty of researching context. As discussed earlier, it is perfectly possible to draw impressive diagrams highlighting multiple contextual features at different levels. However we must remember that whilst these diagrams can be useful heuristic devices, they are not reality. As soon as you attempt to study situations empirically these levels collapse into each other as a result of what Johns (2006) calls the cross level effect. For example, whilst they may be presented at different levels, it is very difficult to separate the impact of regional and and national government initiatives from each other as they are clearly interconnected. Second, each aspect of context impacts on each other in a range of ways and the idea of levels seems to force understandings into a topdown, bottom up, or in-out perspective that isn't very helpful. As we have suggested elsewhere, elements of context intersect and overlap with one another to form a thickly textured web, within which the individual is at once suspended, and is actively weaving (Geertz 1973)' (Authors 2006, p. 1147). Conceptualizing context in terms of faces involves the recognition that each face is part of the whole and that these different aspects or manifestations of context are interlinked, together impacting on individual career-making over time.

It is also important that we do not fall into the trap of contextual determinism and lose sight of the role of agency. As we discussed earlier, particularly with regard to enduring structural features and proximal events, context offers both constraint and structures of opportunity or enablement. Individuals, depending 
upon the resources they have available to them and their mode of engagement (Authors, 2006), will act in different ways. As we highlighted earlier, in different situations some may take a predominantly deterministic view, privileging social structures, others champion free will and their own capacity for action. This interaction between individuals and their context is an area where career studies can and should flourish, developing more theoretically sophisticated understandings of the relationship between structure and agency. As a starting point, the framework developed by Emirbayer and Mische could be useful here. They characterize agency as 'a temporally embedded process of social engagement', informed by the past (in its "iterational" or habitual aspect) but also oriented toward the future (as a "projective capacity to imagine alternative possibilities) and toward the present (as a "practicalevaluative" capacity to contextualize past habits and future projects within the contingencies of the moment). (Emirbayer and Mische (1998, p. 962). Emirbayer and Mische's framework provides a valuable tool for examining the ways in which individuals interact with the various faces of context identified in our findings. For example, taking ideology we can see how existing ways of thinking underpinned much of the routine career behaviour of the actors involved and their views of what was legitimate and possible were deeply embedded within this. Similarly that influenced their ability to deal with contingencies and evaluate the options available to them.

The purpose of this paper was to contribute to the debate about the role and importance of context in career making and to illustrate its impact through analysis of one case study. Clearly the setting is an exceptional one, where a global financial crisis triggered huge cuts in public spending which resulted in dramatic changes to peoples working lives in public social services. This extreme (Yin 2011) case and the in-depth methodology which we employed enabled us to highlight the three faces of context and the ways in which they interweaved. The study suggests a number of areas for further research: Firstly to examine the extent to which these faces operate in alternative situations, for example where change has been less dramatic or where the situation is less politicised. Further it would be interesting to examine the impact of context upon those with less career capital or volition, as suggested by colleagues from vocational psychology. Finally, this paper develops the point recently made by Gunz and Mayrhofer (2015) that career actors are not always individuals (see also Schultheiss, 2007; Blustein, 2011). They highlight other 
types of actor, 'for example a dyad, or a collective actor of higher social complexity (Parsons \& Shils, 1962 (Orig. 1951); Coleman, 1990) such as a group, a social network, or an organization' (p. 12). The senior managers who were involved in this research viewed themselves as a group, whose career decision making was very much intertwined. This suggests an additional important area for future research. 


\section{References}

Al-Ariss, A., Koal, I., Özbilgin, M.,. \&. Suutari, V. (2012). Careers of skilled migrants: Towards a theoretical and methodological expansion. Journal of Management Development, 31, 92-101.

Ali, S.R., Fall, K., \& Hoffman, T. (2013). Life without work: Understanding social class changes and unemployment through theoretical integration. Journal of Career Assessment, 21, 111-126.

Bansal, P. and Corley, K. (2011). The coming of age for qualitative research: Embracing the diversity of qualitative methods. Academy of Management Journal, 54, 233-237.

Barley, S. (1989). Careers, identities and institutions. In. M.B. Arthur, D.T. Hall \& B.S. Lawrence (Eds.) Handbook of Career Theory (pp. 41-50). Cambridge: Cambridge University Press.

Blustein, D. (2011). A relational theory of working. Journal of Vocational Behavior, 79, 1-17.

Blustein, D., Schultheiss, D.E.P., \& Flum, H. (2004). Toward a relational perspective of the psychology of careers and working: A social constructionist analysis. Journal of Vocational Behavior, 64, 423-440.

Cohen, L., Duberley, J., \& Mallon, M. (2004). Social constructionism in the study of career: Accessing the parts that other approaches ca not reach. Journal of Vocational Behavior, 64, 407-422.

Coleman, (1990) cited in Gunz, H., Mayrhofer, W., \& Tolbert, P. S. (2011). Introduction to special section: Careers in context Retrieved 15 June 2015, from Cornell University, ILR School site: http://digitalcommons.ilr.cornell.edu/articles/503/

Dries, N. (2011). The meaning of career success. Career Development International, 16, 364-384.

Duberley, J., Cohen, L., \& Mallon, M. (2006). Constructing scientific careers: Change, continuity and context. Organization Studies, 27, 1131-1151.

Duffy, R., \& Dik, B. (2009). Beyond the self: External influences in the career development process. The Career Development Quarterly, 58, 29-43.

Eaton, S. C., \& Bailyn, L. (2000 ) Career as life path: Tracing work and life strategies of biotech professionals. In M. Peiperl, M. Arthur, R. Goffee, \& T. Morris (Eds.) Career frontiers: New conceptions of working lives (pp.177-198). Oxford: Oxford University Press.

Emirbayer, M.. \& Mische, A. (1998). What is agency? American Journal of Sociology, 103, 962-1023. 
Forrett, M.L., Sullivan, S.E., \& Mainiero, L.A. (2010). Gender role differences in reactions to unemployment: Exploring psychological mobility and boundaryless careers. Journal of Organizational Behavior, 13, 647-666.

Geertz, C. (1973). The interpretation of culture. New York: Basic Books.

Giddens, A. (1984). The constitution of society. Cambridge: Polity Press.

Gioia, D., Corley, K., \& Hamilton, A. (2012). Seeking qualitative rigor in inductive research: Notes on the Gioia methodology. Organizational Research Methods, 16, 15-3

Gladwell, M. (2008). Outliers: The story of success. London: Penguin.

Grote, G and Hall, D. (2013). Reference groups: A missing link in career studies. Journal of Vocational Behavior, 83, 265-279.

Guba, E.G., \& Lincoln, Y.S. (1989). Fourth generation evaluation. California: Sage Publications.

Gunz, H., \& Mayrhofer W. (2011). Re-conceptualizing career success: A contextual approach. Journal of Labour Market Research, 32(12), 251-260.

Gunz H., \& Mayrhofer, W. (2015). The social chronology framework: A multi-perspective approach to career studies. SSRN Working Paper.

Gunz, H., Mayrhofer, W., \& Tolbert, P. S. (2011). Introduction to special section: Careers in context Retrieved 15 June 2015, from Cornell University, ILR School site:

http://digitalcommons.ilr.cornell.edu/articles/503/

Hammersley, M. \& Atkinson, P. (1995). Ethnography: Principles in practice. London: Routledge.

Hanchey, J., \& Berkelaar, B. (2015). Context matters: Examining discourses of Career Success in Tanzania. Management Communication Quarterly, 1-29.

Inkson, K., Gunz, H., Ganesh, S., \& Roper, J. (2012). Boundaryless careers: Bringing back boundaries. Organization Studies, 33, 323-340.

Johns, G. (2006). The essential impact of context on organizational behaviour. Academy of Management Review, 31, 386-408. 
Kang, Z., \& Gottfredson, G. (2015). Environments: Diversity in theoretical foundations of career interventions. In P. Hartung,,M. Savickas, \& W. Walsh W. (Eds.) APA Handbook of Career Interventions Vol 1. Foundations (pp. 159-185). Washington: American Psychological Association.

Kaulisch, M., \& Enders, J. (2005). Careers in overlapping institutional contexts: The case of academe. Career Development International, 10, 130-144.

Kvale, S. (1996). InterViews: An introduction to qualitative research interviewing, London: Sage.

Lee, M.D., Kossek, E. E., Hall, D.T.. \& Litrico, J.B. (2011). Entangled strands: A process perspective on Formatted: Dutch (Netherlands) the evolution of careers in the context of personal, family, work and community life. Human Relations, 64, 1531-1553.

Mainiero, L., \& Sullivan, S. (2005). Kaleidoscope careers: An alternative explanation for the 'opt-out' revolution. Academy of Management Executive, 19, 106-123.

Mannheim, K. (1936/98). The sociological problem of generations. In essays on the sociology of knowledge: The collected works of Karl Mannheim (pp 163-195). London: Taylor and Francis.

McMahon, M., Watson, M., \& Patton, W. (2014). Context resonant systems perspectives in career theory. In G. Arulmani (Ed.) Handbook of Career Development (pp 29-41). New York: Springer.

Mayrhofer, W., Meyer, M., \& Steyer, J. (2007). Contextual issues in the study of career. In H. Gunz \& M. Peiperl, M. Eds.) Handbook of Career Studies (pp 251-240). London: Sage.

Meyer, A. (1982). Adapting to environmental jolts. Administrative Science Quarterly, 27, 515-537. Parsons \& Shils (1962). cited in Gunz, H., Mayrhofer, W., \& Tolbert, P. S. (2011). Introduction to special section: Careers in context. Retrieved 15 June 2015, from Cornell University, ILR School site: http://digitalcommons.ilr.cornell.edu/articles/503/

Patton, M (2015) Qualitative research and evaluation methods: Integrating theory and practice. London: Sage.

Patton, W., Doherty, C., \& Shield, P. (2014). The extended context of career: Families negotiating education and career decisions. Australian Journal of Career Development, 23, 69-78.

Patton, W. \& McMahon, M. (2015). The systems theory framework of career development: 20 years of contribution to theory and practice. Australian Journal of Career Development, 23, 141-147. 
Richardson, M.S. (2000). A new perspective for counselors: From career ideologies to empowerment through work and relationship practices. In A. Collin \& R. Young (Eds.) The future of career (pp. 197211). Cambridge: Cambridge University Press.

Rossi, A. (1992). Seasons of a woman's life. In B. Berger (Ed.) Authors of Their Own Lives (pp. 301-322). Oxford: University of California Press.

Savickas, Mark L. (2005). The theory and practice of career construction. In S.D. Brown \& R.W. Lent (Eds.) Career development and counseling: Putting theory and research to work (pp42-70). NJ: John Wiley \& Sons.

Savickas, M., Nota,L., Rossier, J., Dauwalder, J.P., Duarte, M., Guichard, J., Soresi, S.,Van Esbroeck., R., \& Van Vianen, A. (2009). Life designing: A paradigm for career construction in the $21^{\text {st }}$ century. Journal of Vocational Behavior, 75, 239-250.

Schutheiss, D.E.P. (2007) The emergence of a relational cultural paradigm for vocational psychology. International Journal for Educational and Vocational Guidance, 7, 191-201.

Shepherd, D., \& Sutcliffe, K. (2011). Inductive top-down theorizing: A source of new theories of organization. Academy of Management Review, 36, 361-380.

Silverman, D. (2000). Doing qualitative research, $4^{\text {th }}$ edition. London: Sage.

Super, D.E. (1990). A life-span, life-space approach to career development. In Brown, D. Brooks, L. \& Associates (Eds.) Career Choice and Development, $2^{\text {nd }}$ edition (pp197-261). San Francisco: Jossey-Bass. Van Manaan, J. (1979). The fact of fiction in organizational ethnography. Administrative Science Quarterly, 24, 539-550.

Watson, T. (2008). Managing identity: Identity work, personal predicaments and structural circumstances. Organization 15, 121-43.

Weick, K. (1995). Sensemaking in Organizations. London: Sage

Wright, C., Manning, M., Farmer, B. \& Gilbreath, B. (2000). Resourceful sensemaking in product development teams. Organization Studies 21, 807-825.

Yin, R. (2011). Qualitative Research from Start to Finish. New York City, NY: Guilford 